\title{
Perjanjian Kemitraan Ekonomi Komprehensif Regional (Regional Comprehensive Economic Partnership-RCEP) Dan Pengaruhnya Untuk Indonesia
}

\author{
Mochamad Rifki Maulana \\ Magister Hukum Ekonomi, Universitas Indonesia \\ m.rifki91@ui.ac.id, rifkimaulanaya@gmail.com
}

\begin{abstract}
Abstrak. Indonesia yang merupakan anggota ASEAN dan memimpin di tahun 2011 mencoba mengkonsolidasikan perjanjian perdagangan antara ASEAN dengan mitra-mitra dagangnya. Konsolidasi perjanjian tersebut berhasil diwujudkan di tahun 2020 dan saat ini dikenal sebagai Perjanjian Kemitraan Ekonomi Komprehensif Regional (Regional Comprehensive Economic Partnership) yang disingkat RCEP. Gagasan dari adanya perjanjian tersebut adalah untuk membuka perdagangan jasa, menurunkan tarif, dan mempromosikan investasi untuk membantu negara-negara berkembang seperti Asia untuk mengejar ketertinggalan dunia. Metodologi dalam tulisan ini bersifat yuridis normatif, dengan tujuan penulisannya yang berfokus untuk mengetahui isi Perjanjian RCEP secara umum dan bagaimana pengaruhnya untuk Indonesia. Kesimpulan dari tulisan ini adalah sebagai upaya dalam memperluas dampak di perdagangan internasional dan menaikkan pendapatan negara, Pemerintah Indonesia menggagas Perjanjian Kemitraan Ekonomi Komprehensif Regional (RCEP) yang membuka peluang tersebut dengan skala yang cukup besar bagi Indonesia.
\end{abstract}

\section{Kata Kunci: Perjanjian Kemitraan Ekonomi Komprehensif Regional, Hukum Internasional}

Abstract. Indonesia, which is a member of ASEAN and led the organization in 2011, is trying to consolidate trade agreements between ASEAN and its trading partners. The agreement consolidation was successfully realized in 2020 and is currently known as the Regional Comprehensive Economic Partnership (RCEP). The idea behind the agreement is to open up trade in services, lower tariffs and promote investment to help developing countries like Southeast Asia to catch up with the world. The methodology in this paper is descriptive normative, with the aim of writing that focuses on knowing the contents of the RCEP Agreement in general and how it affects Indonesia. The conclusion of this paper is that as an effort to expand the impact on international trade and increase state revenues, the Government of Indonesia initiated a Regional Comprehensive Economic Partnership Agreement (RCEP) which opens up these opportunities on a large enough scale for Indonesia.

Keywords: Regional Comprehensive Economic Partnership, International Law

\section{PENDAHULUAN}

Pada tanggal 15 November 2020, Indonesia menandatangani Perjanjian Kemitraan Ekonomi Komprehensif Regional atau dalam bahasa inggris dikenal sebagai Regional Comprehensive Economic Partnership yang disingkat RCEP di Istana Bogor. Penandatanganan dilakukan oleh Presiden Republik Indonesia Joko Widodo dan Menteri Perdagangan Republik Indonesia Agus Suparmanto di sela-sela Konferensi Tingkat Tinggi (KTT) ASEAN ke-37. RCEP sendiri merupakan gagasan dari Indonesia saat memegang kepemimpinan ASEAN di tahun 2011 silam. Negosiasi dimulai di tahun 2013 yang dipimpin oleh Imam Pambagyo, Direktur Jenderal Perundingan Perjanjian Internasional Kementerian Perdagangan dengan dukungan dari Sekretariat ASEAN. Perundingannya dinyatakan selesai pada 11 November 2020 dengan 15 negara yang menyepakatinya terdiri dari 10 negara ASEAN dan 5 mitra ASEAN yaitu Tiongkok, Jepang, Korea Selatan, Australia, dan Selandia Baru. Kerja sama ini bertujuan untuk mengonsolidasikan lima perjanjian perdagangan bebas (Free Trade 
Agreement/FTA) yang sudah dimiliki ASEAN dengan enam mitra dagangnya, dimana pada perjanjian ini India memutuskan untuk tidak menandatangani perjanjian tersebut.

Penandatanganan RCEP merupakan peristiwa historis, dimana perjanjian mendukung peran ASEAN dalam memimpin perjanjian dagang multilateral dalam skala besar, walaupun dihadapi dengan kondisi global terkini dan 8 (delapan) tahun negosiasi. RCEP merupakan perjanjian dagang terbesar ASEAN sampai saat ini, dimana mencakup pasar sebanyak 2,2 milyar orang dengan nilai pasar sebesar US\$ 26,2 triliun atau 30\% dari Produk Domestik Bruto (PDB) dunia. Melihat skala perjanjian dan besarnya peran Indonesia pada perjanjian tersebut, menarik untuk melihat bagaimana perjanjian RCEP dapat memengaruhi Indonesia ke depannya. Oleh karena itu, penulis tertarik untuk mengulas lebih lanjut tentang RCEP dan dampaknya pada artikel ini dengan rumusan masalah sebagai berikut:

1. Apa itu Perjanjian Kemitraan Ekonomi Komprehensif Regional (Regional Comprehensive Economic Partnership/RCEP) dan bagaimana pengaturannya?

2. Bagaimanakah RCEP dapat memengaruhi Indonesia, baik secara keuntungan (manfaat) dan tantangan yang akan dihadapi setelah meratifikasi RCEP?

Dalam artikel ini, tujuan umum penulis yaitu untuk menambah pengetahuan dan wawasan mengenai Hukum Perjanjian Internasional. Sedangkan tujuan khusus dalam artikel ini adalah:

1. Untuk mengetahui apa itu Perjanjian Kemitraan Ekonomi Komprehensif Regional (RCEP);

2. Untuk mengetahui bagaimana pengaturan RCEP; dan

3. Untuk mengetahui bagaimana manfaat dan tantangan RCEP bagi Negara Indonesia.

\section{METODE PENELITIAN}

Metode yang digunakan dalam penulisan artikel ini adalah metode pendekatan yuridis normatif. Yuridis normatif yaitu penulisan karya ilmiah yang didasarakan pada studi kepustakaan dan menelaah konsep, pendapat ataupun penemuan yang berhubungan dengan permasalahan hukum yang diangkat dalam topik penulisan. Penulis mengkaji perjanjian, konsep dan pendapat hukum berdasarkan bahan hukum secara studi kepustakaan yang berkaitan dengan Perjanjian Kemitraan Ekonomi Komprehensif Regional (Regional Comprehensive Economic Partnership /RCEP).

\section{HASIL DAN PEMBAHASAN}

Regional Comprehensive Economic Partnership (RCEP) dan Pengaturannya Regional Comprehensive Economic Partnership (RCEP) atau Kemitraan Ekonomi Komprehensif Regional adalah pakta perdagangan besar yang diusulkan oleh ASEAN untuk meningkatkan perdagangan di antara negara-negara anggotanya ditambah dengan mitra perjanjian perdagangan bebas (Free Trade Agreement/FTA). Negara yang terlibat termasuk 10 anggota ASEAN, yaitu Brunei Darussalam, Kamboja, Indonesia, Laos, Malaysia, Myanmar, Filipina, Singapura, Thailand, dan Vietnam, dan lima mitra FTA ASEAN yakni Australia, China, Jepang, Selandia Baru dan Korea Selatan. Kelima belas negara penandatangan perjanjian RCEP ini secara kumulatif mewakili 29,6 (persen) penduduk dunia, 30,2 persen GDP (gross domestic product) dunia, 27, 4 persen perdagangan dunia, dan 29,8 persen FDI (foreign direct investment) dunia. RCEP merupakan kesepakatan trading block terbesar di dunia, meskipun India pada akhirnya memutuskan untuk tidak bergabung, RCEP tetap menjadi perjanjian perdagangan terbesar di dunia, di luar WTO.

Tujuan dari RCEP adalah untuk menurunkan tarif, membuka perdagangan jasa, dan mempromosikan investasi untuk membantu negara-negara berkembang mengejar ketertinggalan dunia. Secara khusus, RCEP diharapkan dapat membantu mengurangi biaya dan waktu bagi perusahaan dengan memungkinkan mereka mengekspor produk ke mana pun di dalam blok tanpa memenuhi persyaratan terpisah untuk setiap 
negara. Perjanjian RCEP ini juga menyentuh kekayaan intelektual, tetapi tidak akan mencakup perlindungan lingkungan dan hak tenaga kerja. Negara-negara yang tergabung dalam RCEP ini juga berjuang untuk sepenuhnya menyetujui beberapa ketentuan tentang perdagangan digital.

Perjanjian RCEP memiliki 20 Bab, 17 Annex dan 54 jadwal komitmen yang mencakup akses pasar, peraturan dan disiplin, serta kerja sama ekonomi dan teknis. Target RCEP adalah untuk menetapkan kerja sama ekonomi yang modern, komprehensif, berkualitas tinggi dan menguntungkan seluruh pihak yang akan memfasilitasi ekspansi perdagangan regional dan investasi serta berkontribusi pada pertumbuhan dan perkembangan ekonomi global. Perjanjian ini akan membuka peluang pasar dan pekerjaan kepada bisnis dan masyarakat. Perjanjian RCEP akan bekerja bersampingan dan mendukung sistem perdagangan multilateral yang terbuka inklusif dan berdasarkan peraturan.

Pada target RCEP disebutkan 4 (empat) komponen/fitur utama dari RCEP yaitu modern, komprehensif, berkualitas tinggi, dan menguntungkan sesama atau keuntungan mutual. Fitur-fitur utama ini menjadi keunggulan dari RCEP. Terkait modernitas, RCEP dirancang tidak hanya untuk masa kini namun juga untuk masa depan. Perjanjian RCEP memperbarui cakupan dari perjanjian ASEAN + 1 Mitra FTA yang sudah ada dan mempertimbangkan realita dagang yang sedang muncul dan akan datang, termasuk electronic commerce (e-commerce), potensi usaha mikro, kecil, dan menengah (UMKM), pendalaman rantai nilai regional dan kompleksitas kompetisi pasar. Perjanjian RCEP akan melengkapi Organisasi Dagang Dunia (World Trade Organization/WTO), dimana RCEP membangun dari Perjanjian WTO di area yang dimana para pihak setuju untuk memperbarui atau mengatur lebih jauh dari pasal-pasal di perjanjian WTO. Selain modern, RCEP merupakan perjanjian yang komprehensif, baik secara cakupan maupun kedalaman komitmen. Secara cakupan, RCEP terdiri dari 20 Bab dan mengatur berbagai area yang belum dijamah oleh perjanjian antara ASEAN dengan mitra FTA-nya. RCEP memiliki pasal-pasal spesifik yang mengatur perdagangan barang (trade in goods), termasuk aturan asal, prosedur bea cukai dan fasilitasi dagang, langkah sanitasi dan fitosanitasi, standar, pengaturan teknis, dan prosedur asesmen kesesuaian, serta solusi perdagangan. RCEP juga mengatur jasa perdagangan yang melingkupi jasa keuangan, jasa telekomunikasi dan jasa professional lainnya, termasuk juga perpindahan sementara manusia/subjek hukum natural (natural person). Selain itu, terdapat pengaturan mengenai investasi, hak kekayaan intelektual, e-commerce, persaingan usaha, usaha mikro, kecil, dan menengah, kerja sama ekonomi dan teknis, pengadaan public, serta area legal dan institusional seperti penyelesaian sengketa. Dalam hal akses pasar, perjanjian RCEP memberikan kebebasan dalam perdagangan barang dan jasa serta memiliki cakupan yang luas terkait investasi.

RCEP merupakan perjanjian yang berkualitas tinggi, dimana perjanjian ini mengandung pasal-pasal yang melampaui perjanjian FTA eksisting ASEAN namun tetap mempertimbangkan individualitas dan level beragam perkembangan dan kebutuhan ekonomi dari pihak-pihak yang terlibat dalam RCEP. Perjanjian RCEP membahas masalah yang diperlukan untuk mendukung keterlibatan para pihak dalam rantai pasokan global dan regional serta melengkapi komitmen akses pasar dengan aturan yang memungkinkan perdagangan dan investasi yang memfasilitasi bisnis, sementara pada saat yang sama mempertahankan tujuan kebijakan publik yang sah. Perjanjian RCEP berupaya untuk meningkatkan persaingan dengan cara mendorong produktivitas yang berkelanjutan, bertanggung jawab, dan konstruktif. Selain itu, Perjanjian RCEP memiliki nilai tambah dengan menyatukan satu buku peraturan untuk membantu memfasilitasi pengembangan dan perluasan rantai pasokan regional di antara para pihak. Perjanjian RCEP menyatukan negara-negara dengan berbagai tingkat pembangunan. Dengan demikian, Pihak RCEP telah mengakui bahwa keberhasilannya akan 
ditentukan oleh kemampuannya untuk saling membawa manfaat. Perjanjian RCEP dirancang untuk mencapai tujuan ini dalam berbagai cara, termasuk melalui berbagai bentuk fleksibilitas dan ketentuan yang sesuai untuk perlakuan khusus dan berbeda terutama untuk Kamboja, Laos, Myanmar, dan Vietnam, dan fleksibilitas tambahan untuk negara yang perkembangannya masih kurang dibandingkan pihak lain. Selain itu, Perjanjian RCEP mencakup kerja sama teknis dan pengembangan kapasitas yang akan tersedia untuk mendukung implementasi komitmen yang dibuat berdasarkan Perjanjian RCEP dan bagi para pihak untuk memaksimalkan manfaat yang diperoleh darinya. Perjanjian RCEP juga mencakup ketentuan yang akan memastikan bahwa ekonomi dengan tingkat pembangunan yang berbeda, bisnis dengan ukuran yang berbeda, dan pemangku kepentingan yang lebih luas semuanya dapat memperoleh manfaat dari perjanjian ini.

\section{Pengaruh Regional Comprehensive Economic Partnership (RCEP) Bagi Indonesia}

Sekretaris ASEAN pada tanggal 15 November 2020, bertepatan dengan penandatanganan Regional Comprehensive Economic Partnership (RCEP) menyatakan berbagai manfaat yang diharapkan dari perjanjian ini. Yang paling utama, RCEP diharapkan dapat membantu dalam pemulihan ekonomi yang cepat dan tangguh untuk bisnis dan penduduk di negara ASEAN di tengah pandemi Covid-19 ini. Perjanjian RCEP akan meningkatkan akses pasar dengan menghapuskan tarif dan kuota di lebih dari $65 \%$ barang yang diperdagangkan dan membuat bisnis lebih dapat diprediksi dengan aturan asal yang sama (common rules of origin) dan regulasi yang transparan setelah diberlakukan. Hal tersebut akan mendorong perusahaan untuk berinvestasi lebih banyak di kawasan ini, termasuk membangun rantai pasokan dan layanan, dan untuk menciptakan lapangan kerja.

RCEP akan mengurangi biaya perdagangan dan menciptakan kerangka kerja sama antara pejabat di kawasan perdagangan.
Anggota perjanjian akan menghubungkan kekuatan mereka dalam bidang teknologi, manufaktur, pertanian, dan sumber daya alam. Ekonomi mereka akan menjadi lebih efisien secara individu dan, sebagai sebuah blok, lebih kompetitif secara global. Asia Timur juga akan menjadi lebih menarik bagi investor dan mitra dagang dari Eropa dan Amerika Latin. Perjanjian yang lebih dalam, misalnya di antara China, Jepang, dan Korea Selatan, mungkin menyusul.

The Peterson Institute for International Economics mengestimasi bahwa perjanjian RCEP dapat menaikkan pendapatan negara global sampai \$186 milyar per tahun pada tahun 2030 dan menambah $0,2 \%$ untuk pertumbuhan ekonomi para pihak. RCEP dapat meningkatkan akses ke dana Belt and Road Initiative (BRI) China, meningkatkan keuntungan dari akses pasar dengan memperkuat jaringan transportasi, energi, dan komunikasi. Pengaturan terkait aturan asal (rule of origin) RCEP yang menguntungkan juga akan menarik investasi asing. RCEP adalah kemenangan diplomasi kekuatan menengah ASEAN. Potensi nilai dari perjanjian perdagangan Asia Timur yang besar telah lama diakui, tetapi baik China maupun Jepang, ekonomi terbesar di kawasan itu, tidak dapat disebut secara politik sebagai arsitek proyek tersebut. Kebuntuan tersebut diselesaikan pada tahun 2012 dengan kesepakatan yang ditengahi ASEAN yang memasukkan India, Australia, dan Selandia Baru sebagai anggota, dan menempatkan ASEAN yang bertanggung jawab untuk merundingkan perjanjian tersebut. Tanpa "sentralitas ASEAN" seperti itu, RCEP mungkin tidak akan pernah diluncurkan.

Penandatanganan RCEP tidak hanya menjadi tonggak pencapaian kerjasama regional Asia Timur, tetapi juga kemenangan multilateralisme dan perdagangan bebas menurut Perdana Menteri China Li Keqiang. Kesimpulan dari negosiasi RCEP akan mengirimkan pesan yang kuat tentang peran utama ASEAN dalam mendukung sistem perdagangan multilateral, membantu menciptakan struktur perdagangan baru di kawasan, memfasilitasi perdagangan secara 
berkelanjutan, mengembangkan rantai pasokan yang terganggu, dan mendukung pasca pandemi. pemulihan menurut Perdana Menteri Vietnam Nguyen Xuan Phuc. Sedangkan menurut Menteri Perindustrian dan Perdagangan Internasional Malaysia Mohamed Azmin Ali, penandatanganan perjanjian RCEP akan menjadi bukti dunia atas upaya memperkuat sistem perdagangan multilateral dan menegakkan agenda pembangunan di Organisasi Perdagangan Dunia (WTO). RCEP adalah perjanjian yang sangat signifikan secara simbolis, datang pada saat ketidakpastian perdagangan global menurut Menteri Perdagangan, Pariwisata dan Investasi Australia Simon Birmingham.

Di dalam peran ASEAN tersebut, Indonesia menjadi sorotan. Indonesia telah memainkan peran penting dalam negosiasi. Sebagai ekonomi terbesar ketujuh di dunia dan terbesar di ASEAN - Indonesia berkepentingan untuk melihat kesepakatan perdagangan ini diselesaikan. Pertama, ini akan membantu Indonesia memperluas pasarnya dan berintegrasi lebih jauh ke dalam rantai pasokan global. Kedua, RCEP hadir pada saat yang tepat sebagai pelengkap Omnibus Law yang baru saja disahkan dalam mewujudkan reformasi struktural di Indonesia. Hal Ini bahkan lebih penting mengingat perkembangan multilateralisme yang lamban dan terganggunya perdagangan global yang disebabkan oleh pandemi COVID-19.

Menurut Menteri Perdagangan Republik Indonesia Agus Suparmanto, Indonesia dapat diuntungkan dari segi ekspor dan investasi. Dengan ditandatangani dan akan diratifikasinya RCEP, maka perjanjian tersebut berpotensi meningkatkan ekspor Indonesia ke negara-negara peserta sebesar 8$11 \%$. Investasi ke Indonesia juga berpotensi meningkat $18-22 \%$. Melalui RCEP, Indonesia juga dapat menikmati spillover effect dari Perjanjian Dagang Bebas (Free Trade Agreement/FTA) yang dimiliki negara anggota RCEP dengan negara-negara non-anggota. Perluasan peran Indonesia melalui rantai pasok global dari spillover effect ini berpotensi meningkatkan ekspor Indonesia ke dunia sebesar 7,2\%. Data ekspor Indonesia ke 14

Jurnal Ilmu Sosial dan Pendidikan negara RCEP selama 5 tahun terakhir menunjukkan tren positif sebesar 7,35\%. Pada tahun 2019, total ekspor non-migas ke kawasan RCEP mewakili 56,51\% total ekspor Indonesia ke dunia, yakni senilai US\$84,4 miliar. Sementara dari sudut impor, RCEP mewakili $65,79 \%$ total impor Indonesia dari dunia, yakni senilai US\$102 miliar.

Selain kenaikan pada ekspor dan investasi, RCEP berpotensi menaikkan Pendapatan Domestik Bruto (Gross Domestic Product/GDP) Indonesia. Berdasarkan kajian Badan Kebijakan Fiskal (BKF) pada tahun 2019, dinyatakan bahwa Indonesia bisa meningkatkan GDP $0,05 \%$ selama periode 2021-2032 bila meratifikasi RCEP. Namun sebaliknya bila tidak meratifikasi RCEP, maka GDP Indonesia akan mengalami penurunan $0,07 \%$ selama periode yang sama, yaitu 2021 2032.

Kajian lain yang dilakukan Kemendag pada 2016 pun menunjukkan RCEP ini akan memberikan welfare gain bagi Indonesia sekitar US\$ 1,52 miliar. Welfare gain merupakan surplus yang didapatkan konsumen dan produsen dari sebuah transaksi. Dari perspektif konsumen, welfare gain dapat diperoleh bila harga yang mampu dibayar konsumen lebih besar dari harga faktual di pasar, sementara dari perspektif produsen, welfare gain dapat diperoleh bila harga yang mampu mereka tawarkan ke pasar lebih kecil dari harga faktual di pasar.

Pengusaha Indonesia juga akan memeroleh sejumlah keuntungan, khususnya terkait ekspor produk. Pengusaha, baik besar maupun kecil, yang ingin mengekspor produk mereka ke negara-negara RCEP tidak lagi perlu menggunakan SKA (surat keterangan asal) yang berbeda-beda sesuai negara tujuan. Untuk produk yang sama, sepanjang memenuhi origin criteria yang diatur dalam RCEP, pengusaha kita cukup mengantongi SKA RCEP untuk mengekspor satu produk ke semua negara RCEP. Produk-produk yang dapat didorong ekspornya dengan memanfaatkan RCEP antara lain serat berbahan dasar tanaman, kertas dan bubur kertas, karet dan produk karet, beberapa produk mineral dan logam, jasa gas dan 
kelistrikan, produk kayu, dan produk makanan termasuk hasil perikanan.

RCEP harus lebih meningkatkan hubungan intra-perdagangan IndonesiaASEAN yang sangat diandalkan Indonesia. 25\% dari total ekspor Indonesia masuk ke ASEAN dan $23 \%$ dari total impornya berasal dari ASEAN pada tahun 2019. Sebagian besar merupakan hasil dari penghapusan kerumitan yang terkait dengan aturan asal (rule of origin) dalam perjanjian perdagangan yang melibatkan negara-negara ASEAN. Mengurangi hambatan perdagangan regional merupakan langkah penting untuk mempertahankan perdagangan dan menegakkan persaingan serta efisiensi. Arus perdagangan yang meningkat cenderung mendorong lebih banyak investasi asing langsung (Foreign Direct Investment/FDI). Hal ini sejalan dengan seruan berulang kali dari Presiden Joko Widodo untuk meningkatkan aliran masuk FDI ke Indonesia. Penghapusan tarif adalah fitur utama RCEP. Sebuah studi menemukan bahwa pemotongan tarif $1 \%$ oleh anggota RCEP akan meningkatkan perdagangan Indonesia rata-rata lebih dari $2 \%$, dengan mengendalikan faktorfaktor lain.

Namun begitu, masih ada pihak yang tidak sependapat mengenai keuntungan RCEP bagi Indonesia. Menurut Ekonom PBB untuk Perdagangan dan Pembangunan (UNCTAD) Rashmi Banga, ketentuan-ketentuan liberalisasi dalam RCEP akan sangat membatasi ruang kebijakan negara dan menyulitkan negara-negara ASEAN untuk keluar dari krisis multidimensi, kesehatan, ekonomi, dan iklim yang tengah dihadapi saat ini. Menurut analisis Rashmi, kerugian yang akan dialami negara-negara ASEAN dari perjanjian RCEP ini mencapai USD 22 miliar. Indonesia sendiri akan mengalami defisit perdagangan barang hampir USD 1,4 miliar dari kehilangan tarif akibat RCEP. Rashmi melanjutkan, sejumlah sektor di Indonesia seperti otomotif, produks besi baja, gula, dan pangan olahan akan sangat dirugikan. Senada, Direktur Eksekutif Indonesia Global Justice (IGJ) Rachmi Hertanti menyebutkan perjanjian RCEP berpeluang besar merugikan perekonomian dan ruang hidup masyarakat Indonesia. Bila dikalkulasikan, dengan bergabung ke RCEP, ekonomi Indonesia hanya akan tumbuh $0,05 \%$ di tahun 2030. Menurut Rachmi, ini kontras dengan narasi pemerintah yang mengharapkan ekonomi membaik dari RCEP. Justru sebaliknya Indonesia akan menjadi sasaran pasar bagi negara dagang RCEP. Tak hanya itu, setiap perjanjian perdagangan bebas yang dikomitmenkan oleh Pemerintah, menurut Rachmi tidak mengukur analisis dampak HAM, sosial, dan lingkungan dari sebuah perjanjian dagang, termasuk perjanjian RCEP. Tidak adanya analisis dampak HAM, sosial, dan lingkungan ini akan berakibat terhadap pelanggaran hak-hak sosial masyarakat ataupun perampasan ruang hidup rakyat.

$\begin{array}{cccc}\text { Sementara } & \text { Koordinator } & \text { Program } \\ \text { Badan } & \text { Eksekutif } & \text { Nasional } & \text { Solidaritas }\end{array}$ Perempuan, Arie Kurniawaty menilai, pernyataan Menteri Perdagangan bahwa kerja sama ekonomi RCEP akan mendongkrak UMKM adalah klaim yang tidak berdasar. Menurut Arie, hingga hari ini banyak usaha kecil yang dikelola oleh perempuan mengalami kesulitan untuk bangkit akibat terpukul oleh pandemi Covid-19. Dia mempertanyakan dampaknya jika nanti akses pasar terbuka lebar. Banyak perempuan pelaku usaha kecil yang dengan kapasitas terbatas harus bersaing dengan produksi massal dari negara lainnya dengan dukungan dan kapasitas yang lebih maju. Peluang apa yang bisa dimanfaatkan dari RCEP, menurut Arie juga tidak diketahui pasti karena teks yang dinegosiasikan tidak pernah disampaikan kepada publik atau dikonsultasikan. Dirinya menjelaskan, usaha pangan olahan, khususnya skala kecil, merupakan sektor yang sangat banyak dilakoni oleh perempuan. Hal ini karena sangat lekat dengan peran gender yang dilekatkan terhadap perempuan. Berdasarkan data Kemenko PMK, kontribusi UMKM (usaha mikro, kecil, menengah) yang dikelola oleh perempuan terhadap PDB di Indonesia mencapai hingga $9,1 \%$. Arie menilai hilangnya ruang kebijakan dan fiskal akibat perjanjian perdagangan bebas, seperti RCEP tidak bisa dilepaskan dari situasi dalam negeri yang juga 
telah membuka lebar liberalisasi perdagangan dan investasi melalui sejumlah kebijakan, seperti UU Cipta Kerja yang telah disahkan. Ketika di dalam negeri perlindungan hak asasi manusia, tenaga kerja, dan lingkungan hidup semakin disempitkan dengan UU Cipta Kerja, penandatanganan RCEP oleh pemerintah akan secara penuh menyerahkan Indonesia dalam rekonfigurasi liberalisasi ekonomi pasar global melalui ekspansi produksi, distribusi, dan reproduksi kapital. Hal ini dinilai akan memperparah perebutan hak-hak rakyat dan ekonomi nasional yang sudah terpukul akibat pandemi berkepanjangan.

Pengamat ekspor asal Inggris, Alan E. Branch menyatakan bahwa perdagangan bebas yang berimplikasi pada berkurangnya tarif seminimal mungkin dapat membuat rantai pasokan global semakin berkembang. Dengan berkurangnya hambatan perdagangan, perusahaan lebih bebas mencari lokasi pabrik yang ongkos produksi dan distribusinya lebih efisien. Salah satu faktor yang mendorong sebuah perusahaan memindah pabriknya adalah kondisi pasar tenaga kerja di mana pabriknya beroperasi. Negara yang pasar tenaga kerjanya memiliki keahlian sesuai standar perusahaan, jumlahnya memadai, dan gajinya murah akan dilirik perusahaan multinasional. Namun, para pengambil keputusan Indonesia masih punya pekerjaan rumah. Pertama, meskipun dahulu tenaga kerja Indonesia diklaim relatif murah, sekarang, Vietnam telah lebih dikenal sebagai penyedia tenaga kerja yang lebih murah. Kedua, walaupun Indonesia mengunggulkan murahnya tenaga kerja, rata-rata tenaga kerja di Indonesia belum mempunyai kapasitas dan daya saing yang mumpuni karena produktivitasnya dinilai masih kurang, setidaknya menurut Menteri Keuangan Sri Mulyani. Hal ini mengindikasikan bahwa pasar tenaga kerja Indonesia masih perlu mengejar efisiensi. Dilansir dari Kementerian Perdagangan dan Industri Singapura, RCEP bakal mewajibkan negara anggotanya untuk mengurangi tarif hingga 92\%. Artinya, skema rantai pasokan global dapat berubah, seperti adanya potensi perusahan multinasional yang berencana untuk merelokasi pabriknya, termasuk ke Indonesia. Dengan adanya hambatan dagang yang lebih minim, pabrik perusahaan multinasional ditempatkan dimanapun bukan jadi suatu problema besar, selama lokasi pabrik menyediakan bahan mentah dan tenaga kerja yang lebih murah daripada di negara asal perusahaan tersebut. Namun Indonesia masih harus mengejar kapasitas teknologi dan SDM-nya untuk dapat meraih manfaat dari pengurangan tarif ini. Sejauh ini, Indonesia cukup berpengalaman dalam isu relokasi perusahaan multinasional. Pada Juli 2020, menurut Badan Koordinasi Penanaman Modal (BKPM), sebanyak 7 perusahaan multinasional resmi merelokasi pabriknya dari China ke Indonesia dengan total nilai investasi sebesar $\mathrm{Rp} 12,4$ triliun dan diprediksi menyerap 30.000 tenaga kerja. Adanya potensi tenaga kerja yang bisa diserap oleh perusahaan multinasional menjadi sangat penting, karena Indonesia pada 2020 diperkirakan memiliki 11 juta pengangguran.

Kekhawatiran lainnya adalah terkait impor barang dari luar, khususnya China. Alasan ini merupakan salah satu alasan mengapa India akhirnya menarik diri dari RCEP. Negara-negara sedang berkembang di ASEAN, termasuk Indonesia, berpotensi kebanjiran barang impor dari China. Dengan semakin bergantung pada suatu entitas, proses pengambilan kebijakan ASEAN bisa lebih mudah dipengaruhi oleh kepentingan entitas tersebut. Sementara, dalam bidang politik, ASEAN masih perlu menyelesaikan persoalan Laut China Selatan dengan China.Padahal, Indonesia masih mengalami defisit perdagangan atau timpangnya impor dibandingkan ekspor terhadap China pada 2020 sebesar US\$6.6 miliar atau setara dengan Rp 93 triliun. Selain itu, dengan adanya RCEP, pesaing UMKM semakin bertambah dimana kondisi ini berpotensi mengurangi pendapatan UMKM. Dikhawatirkan, UMKM kalah bersaing dengan produk impor yang semakin bertambah akibat efek RCEP. Di satu sisi, pandemi COVID-19 benar-benar menghantam UMKM dan potensi meningkatnya barang impor yang lebih murah bisa mempengaruhi usaha mereka. UMKM sangat vital untuk 
Indonesia karena pada tahun lalu saja menyerap $96 \%$ tenaga kerja.

\section{KESIMPULAN}

Regional Comprehensive Economic Partnership (RCEP) atau Kemitraan Ekonomi Komprehensif Regional memang merupakan suatu peluang besar bagi Indonesia dalam memperluas impact di perdagangan internasional dan menaikkan pendapatan negara. Langkah selanjutnya untuk kesepakatan itu adalah ratifikasi oleh parlemen nasional agar bisa berlaku. RCEP akan berlaku 60 hari setelah enam dari sepuluh anggota ASEAN dan tiga dari lima mitra wicara menyelesaikan proses ratifikasi. Indonesia dan ASEAN selayaknya merayakan finalisasi RCEP. Dalam ekonomi global yang tidak pasti yang tertatih-tatih oleh perang perdagangan dan pandemi virus korona, perjanjian tersebut mengirimkan pesan yang jelas bahwa agenda integrasi ekonomi di Asia terus berjalan.

Namun dengan segala potensi keuntungannya, Indonesia masih harus melakukan langkah-langkah strategis untuk merealisasi potensi tersebut. Selain ratifikasi, Indonesia harus meningkatkan daya saingnya, baik secara teknologi, sumber daya manusia, dan perangkat regulasi yang mumpuni untuk menghadapi dampak RCEP. Indonesia mesti memitigasi tantangan yang muncul dari implementasi perjanjian untuk sektor-sektor yang diperkirakan mengalami persaingan lebih ketat. Upaya mitigasi itu bertujuan agar Indonesia menjadi unggul di pasar domestik, yang akan turut menjadi pasar internasional. peneliti senior Indef (Institute For Development of Economics and Finance), Enny Sri Hartati, mengatakan Indonesia harus mengonsolidasi produk yang disiapkan di perdagangan internasional sebelum bisa mengharapkan kesepakatan RCEP akan membuahkan hasil. Sebab, menurut Enny, Indonesia masih terfokus pada komoditas, sementara prioritas ekspor global terletak di manufaktur. Jika tidak, ia mengatakan Indonesia tidak akan merasakan keuntungan RCEP. Enny menjelaskan bahwa permasalahan fundamental efektivitas kerja sama perdagangan internasional, multilateral maupun bilateral, terletak di dalam negeri, bukan pada kerangka perjanjian perdagangannya itu sendiri.

\section{SARAN}

Bagi Indonesia dan ASEAN, RCEP harus menjadi awal, bukan sebagai akhir, integrasi regional. Seperti perjanjian lain dalam kerangka ASEAN-Plus, RCEP akan ditinjau dan terbuka untuk perbaikan lebih lanjut. Ada peluang untuk liberalisasi lebih lanjut dalam bab-bab RCEP tentang investasi, perdagangan jasa, perdagangan elektronik, persaingan dan pertanian serta tentu saja, gajah di dalam ruangan (atau di luar ruangan, seperti yang lebih baik dikatakan) adalah bahwa India telah memilih untuk berdiri terpisah dari RCEP. Indonesia harus memimpin ASEAN dalam memperdalam hubungan ekonomi kita dengan India. Peningkatan FTA ASEAN-India yang sudah ada, misalnya, harus menjadi agenda.

Selain itu, penjaminan HAM dan ketahanan UMKM yang merupakan aset besar bagi ekonomi Indonesia menjadi prioritas tersendiri. Harus dipastikan bahwa negara menjamin bahwa pekerja perusahaan multinasional yang merelokasi pabriknya benar-benar didominasi oleh warga negara Indonesia dan hak serta kewajibannya dijamin undang-undang. Indonesia juga perlu memperkuat sektor UMKM dengan menyediakan pelatihan tenaga kerja serta pemberian bantuan infrastruktur digital seperti koneksi internet yang cepat dan terjangkau untuk bersaing dengan perusahaan yang telah mapan. Pemangku kepentingan juga wajib menjamin bahwa usaha penguatan UMKM bukan merupakan hambatan dagang yang melanggar kesepakatan.

Terakhir, Indonesia sebaiknya mempererat hubungan kerja sama dengan lawan dagang China, seperti Jepang, Australia, Korea Selatan, maupun Amerika Serikat, untuk menghindari dominasi China di kawasan Asia Tenggara. Jika asal mensahkan tanpa memperhitungkan aspek tenaga kerja, UMKM, maupun politik regional, Indonesia dikhawatirkan hanya menjadi penonton dan menjadi sasaran pasar belaka. Diharapkan Indonesia akan menunjukan sepak terjangnya 
dengan serius dalam menindaklanjuti RCEP ditahun 2021.

\section{DAFTAR PUSTAKA}

Arbar, Thea Fathanar. (2020). Mengenal Perjanjian Dagang RCEP yang Katanya Untungkan Cina. Cnbcindonesia.com.

https://www.cnbcindonesia.com/ne ws/20201116073751-4-

201987/mengenal-perjanjiandagang-rcep-yang-katanyauntungkan-china

ASEAN Secretariat. (2020). Joint Leaders Statement on the Regional Comprehensive Economic Partnership (RCEP). https://asean.org/storage/2020/11/ RCEP-Summit-4-Joint-LeadersStatement-Min-Dec-on-India.pdf

ASEAN Secretariat. (2020). Summary of the Regional Comprehensive Economic Partnership Agreement. https://asean.org/storage/2020/11/ Summary-of-the-RCEPAgreement.pdf

ASEAN Secretariat News. (2020). ASEAN Hits Mistoric Milestone With Signing of RCEP. https://asean.org/asean-hitshistoric-milestone-signing-rcep/

BBC News. (2020). RCEP : Asia-Pasific Countries Form Worlds Largest Trading Bloc. https://www.bbc.com/news/worldasia-54949260

CNN Indonesia. (2020). Mengenal RCEP dan Untungnya Buat Indonesia. https://www.cnnindonesia.com/eko nomi/20201116073151-92570136/mengenal-rcepdan-untungnya-buat-indonesia

Hidayat, Khomarul. (2020). Jadi Blok Perdagangan Terbesar Dunia, Apa Itu RCEP? Seberapa Besar Pengaruh RCEP?. https://newssetup.kontan.co.id/new s/jadi-blok-perdagangan-terbesardunia-apa-itu-rcep-seberapabesar-pengaruh-rcep?page $=1$
Huzaini, Moch Dani Pratama. (2020). Dinilai Merugikan, Pemerintah Didesak Tak Menandatangani Perjanjian RCEP. Hukumonline.com. https://www.hukumonline.com/beri ta/baca/lt5fb00f22e4800/dinilaimerugikan--pemerintah-didesaktak-menandatangani-perjanjianrcep

Intan, Rocky. (2020). What RCEP Can Tell Us About Geopolitics in Asia. https://www.lowyinstitute.org/theinterpreter/what-rcep-can-tell-usabout-geopolitics-asia

Kementerian Keuangan. (2020). Ekspor Indonesia Diprediksi Meningkat 7,2 Persen dari RCEP. https://www.kemenkeu.go.id/publik asi/beritalekspor-indonesiadiprediksi-meningkat-7-2-persendari-rcep/

Kristianto, Yohanes Ivan Adi. (2020). Bagaimana RCEP Bisa Menguntungkan dan Merugikan Indonesia.

https://theconversation.com/bagai mana-rcep-bisa-menguntungkandan-merugikan-indonesia-150453

Kuo, Mercy A. (2020). RCEP : The Future of Trade in Asia. https://thediplomat.com/2020/12/rc ep-the-future-of-trade-in-asial

Muhammad, Hiru. (2020). Perjanjian RCEP, Katalis Pertumbuhan Ekonomi Indonesia. Republika.co.id. https://republika.co.id/berita/qkejw 1380/perjanjian-rcep-katalispertumbuhan-ekonomi-indonesia

Patunru, Arianto A dan Ita Aprilianti. (2020). Indonesia Signed RCEP, What Next? https://www.eastasiaforum.org/202 0/12/03/indonesia-signed-rcepwhat-next/pada

Petri, Peter A dan Michael Plummer. (2020). RCEP : A New Trade Agreement That Will Shape Global Economics and Politics. 
Terakreditasi Peringkat 5 (No. SK: 85/M/KPT/2020)

https://www.brookings.edu/blog/or

der-from-chaos/2020/11/16/rcep-a-

new-trade-agreement-that-will-

shape-global-economics-and-

politics/

Tambunan, Liza. (2020). RCEP : Kesepakatan Dagang Terbesar di Dunia Ditandatangani, Lalu Apa Artinya Bagi Indoensia?. Bbc.com.

https://www.bbc.com/indonesia/ind onesia-54959651

Winarto, Yudho. (2020). Manfaat RCEP, Mendag Agus : Pengusaha Tak Perlu SKA untuk Ekspor Produknya. https://industri.kontan.co.id/news/ manfaat-rcep-mendag-agus-

pengusaha-tak-perlu-ska-untukekspor-produknya

Yuniartha, Lidya. (2020). RCEP Ditandatangani, Ini Manfaat yang Bisa Didapatkan Indonesia. https://nasional.kontan.co.id/news/ rcep-ditandatangani-ini-manfaatyang-bisa-didapatkan-indonesia 